\title{
PROFIL LITERASI KEMARITIMAN GURU BIOLOGI DALAM PEMBELAJARAN IPA SMP NEGERI DI KABUPATEN BINTAN
}

\author{
Trisna Amelia*), Ernis Erlina \\ ${ }^{*}$ Program Studi Pendidikan Biologi, \\ Fakultas Keguruan dan Ilmu Pendidikan \\ Universitas Maritim Raja Ali Haji, Tanjungpinang, Kepulauan Riau, Indonesia \\ Email: trisna.amelia@umrah.ac.id
}

\begin{abstract}
Abstrak
Telah dilaksanakan penelitian deskriptif kualitatif mengenai profil literasi kemaritiman guru biologi dalam pembelajaran IPA SMP Negeri di Kabupaten Bintan pada bulan Mei 2017. Tujuan penelitian ini adalah untuk mengetahui bagaimana literasi kemaritiman guru biologi pada mata pelajaran IPA khususnya biologi SMP Negeri di Kabupaten Bintan. Penelitian ini dilakukan dengan pengambilan data melalui angket dan wawancara terhadap responden, kemudian dianalisis secara deskriptif. Hasil penelitian menunjukkan bahwa literasi kemaritiman guru biologi dalam pembelajaran IPA khususnya biologi SMP Negeri di Kabupaten Bintan masih tergolong rendah.
\end{abstract}

Kata Kunci : literasi kemaritiman, guru biologi, pembelajaran IPA

\section{PENDAHULUAN}

Kepulauan Riau merupakan salah satu provinsi di Indonesia dengan luas wilayah sekitar $252.601 \mathrm{~km}^{2}$, sekitar $95 \%$ merupakan lautan dan hanya sekitar 5\% daratan. Kepulauan Riau termasuk provinsi di Indonesia yang memiliki letak yang strategis (Bappenas: 2015). Kepulauan Riau adalah kawasan perbatasan terdepan, terdiri dari 5 kabupaten dan 2 kota dengan luas perairan dan garis pantai yang panjang, memiliki potensi kelautan yang berlimpah ruah serta kekayaan tambang gas dan minyak yang besar. Kondisi ini menjadikan Kepulauan Riau berpotensi sebagai salah satu poros maritim Indonesia.

Salah satu kabupaten yang terdapat di Kepulauan Riau yang memiliki potensi untuk menunjang terciptanya poros maritim Indonesia adalah Kabupaten Bintan. Kabupaten Bintan secara keseluruhan memiliki luas 88.038,54 $\mathrm{km}^{2}$ (Bappeda Kabupaten Bintan, 2012: 3). Sebagai suatu daerah kepulauan di Propinsi Kepulauan Riau dengan jumlah pulau 241, Kabupaten Bintan memiliki rentang wilayah pantai yang panjang yaitu sekitar 966,54 Km garis pantai serta wilayah laut yang sangat luas yaitu $86.398,33 \mathrm{~km}^{2}$ atau $98,51 \%$ dari total wilayah Kabupaten Bintan (Bappeda Kabupaten Bintan, 2012: 4). Selain itu, Kabupaten Bintan terletak pada posisi yang sangat strategis yaitu tepat berada pada Alur Laut Kepulauan Indonesia (ALKI) yang berseberangan dengan jalur Laut Cina Selatan, Selat Malaka, dan Selat Singapura. Kondisi ini menjadikan perairan Kabupaten Bintan sebagai pusat lalu lintas transportasi laut dan mempunyai nilai strategis untuk perdagangan dan industri. Berdasarkan kenyataan tersebut, dapat ditarik kesimpulan bahwa Kabupaten Bintan dapat berkontribusi dalam pencapaian cita-cita Bangsa Indonesia sebagai negara maritim yang kuat dan mandiri. Posisi yang strategis dan menguntungkan ini merupakan modal dasar keinginan pemerintah untuk menjadikan Indonesia sebagai poros maritim dunia. (Bappenas : 2015).

Menurut Pardosi (2016: 17) untuk menjadi poros maritim bukanlah hal yang mudah. Gagasan Indonesia sebagai poros maritim menjadi tujuan besar untuk masa depan bangsa, mengingat wilayah pesisir dan pulau-pulau kecil di kepulauan Indonesia menyimpan potensi besar (Lasabuda, 2013: 93). Salah satu cara 
untuk dapat mewujudkan cita-cita Indonesia ini adalah menciptakan sumberdaya manusia yang dapat memperkuat kemaritiman di Indonesia guna mempersiapkan diri untuk menghadapi tantangan dan persaingan globalisasi di era maritim dengan menumbuhkan kembali pengetahuan mengenai kemaritiman secara menyeluruh melalui dunia pendidikan yang ada di Kabupaten Bintan, salah satunya pada jenjang Sekolah Mengengah Pertama (SMP). Infiltrasi pemahaman mengenai kemaritiman bagi jenjang pendidikan menunjang reorientasi generasi muda pada kesadaran wawasan nusantara berbasis kebaharian sesuai visi poros maritim dunia.

Pendidikan merupakan wahana untuk meningkatkan dan mengembangkan kualitas Sumber Daya Manusia (SDM), yang nantinya akan berperan dalam penerapan ilmu dan teknologi untuk menyongsong pembangunan Kabupaten Bintan yang berkelanjutan. Seiring dengan perkembangan dunia pendidikan, sekolah dituntut sebagai lembaga pendidikan formal untuk dapat menyesuaikan, menanamkan, dan mengembangkan serta dapat mengenalkan kepada siswa mengenai perkembangan ilmu pengetahuan dengan kearifan lokal yang ada di daerahnya. Sebagai daerah yang sebagian besar merupakan daerah yang dekat dengan pesisir pantai sudah selayaknya siswa di Kabupaten Bintan perlu memahami mengenai kemaritiman sebagai aset identitas masyarakat Kabupaten Bintan. Sarana terbaik untuk memberikan pemahaman mengenai kemaritiman di sekolah adalah melalui literasi kemaritiman. Oleh sebab itu, hendaknya guru mengintegrasikan literasi kemaritiman dalam proses pembelajaran untuk memberikan pemahaman mengenai budaya kemaritiman secara menyeluruh.

Literasi kemaritiman yang dimaksud adalah pemahaman tentang kemaritiman secara menyeluruh, dalam artian tidak hanya paham apa arti dari kemaritiman tetapi mampu mengaplikasikan dan mampu melakukan refleksi diri terhadap lingkungan di sekitarnya, untuk dapat mengetahui kelemahan dan kekuatan serta kontribusi dirinya terhadap kemaritiman di lingkungan sekitarnya. Pemahaman secara menyeluruh tersebut merupakan komponen penting dalam literasi kemaritiman, yang memuat beberapa aspek proses ilmiah. Jadi, dapat dikatakan bahwa literasi kemaritiman terintegrasi ke dalam konsep science literacy. Science literacy pada dasarnya menekankan pada proses ilmiah, sesuai dengan pendapat Diana (2015: 285) dalam salah satu aspek science literacy, yaitu berpikir dan bekerja secara ilmiah.

Untuk menghasilkan generasi muda di Kabupaten Bintan yang berkompeten dan memiliki literasi kemaritiman, tidak terlepas dari peran guru di sekolah. Menurut Djamarah (dalam Al-musyuroh, 2015: 15 ) Guru merupakan salah satu komponen manusiawi dalam proses belajar mengajar yang ikut berperan dalam usaha pembentukan sumber daya manusia yang profesional dibidang pembangunan. Oleh karena itu, guru yang merupakan salah satu unsur di bidang kependidikan harus berperan serta secara aktif dan menempatkan kedudukannya sebagai tenaga profesional, sesuai dengan tuntutan masyarakat yang semakin berkembang.

Menurut Undang-undang Republik Indonesia No.14 Tahun 2005 tentang guru dan dosen menjelaskan bahwa Guru adalah pendidik profesional dengan tugas utama mendidik, mengajar, membimbing, mengarahkan, melatih, menilai, dan mengevaluasi peserta didik pada pendidikan anak usia dini jalur pendidikan formal, pendidikan dasar, dan pendidikan menengah. Sebagai pengajar atau pendidik, guru merupakan salah satu faktor penentu keberhasilan setiap upaya pendidikan. Guru sebagai tenaga pendidik yang memiliki kompetensi profesional selalu dituntut untuk memiliki wawasan yang luas bukan hanya wawasan bidang yang di ampunya tetapi dalam bidang-bidang lain seperti wawasan mengenai kemaritiman serta menguaasai keterampilanketerampilan lainnya dalam aplikasinya dalam kehidupan sehari-hari, sehingga nantinya wawasan tersebut dapat disalurkan kepada peserta didik.

Pemahaman mengenai kemaritiman dan literasi kemaritiman secara menyeluruh dapat diintegrasikan dalam mata pelajaran di sekolah, salah satunya dalam mata pelajaran biologi pada jenjang SMP. Peran guru biologi sangat mendukung terciptanya generasi muda berwawasan kemaritiman karena dalam 
pembelajaran biologi sangat banyak materi pembelajaran yang dapat disisipkan wawasan kemaritiman untuk membangun kembali mengenai kemaritiman serta dapat mengaplikasikannya dalam kehidupan. Disamping pembelajaran biologi lebih menonjolkan alam nyata, banyak tempat di Kabupaten Bintan yang dapat menjadi salah satu media pembelajaran nyata dan berwawasan kemaritiman .

Literasi kemaritiman yang diintegrasikan dalam mata pelajaran biologi mengandung nilainilai kemaritiman untuk membangun kembali budaya maritim yang tujuannya memupuk rasa kepedulian antara warga negara atau masyarakat atas wilayah kelautan dan batas-batasnya sebagai wilayah harga mati NKRI (Indrawanto, 2015: 8). Rasa kepedulian tersebut merupakan salah satu bentuk sikap ilmiah yang harus dipupuk sehingga nilai-nilai kemaritiman yang terkandung didalamnya dapat ditransfer, diwariskan dan dibudidayakan oleh peserta didik.

LIPI (2016) menyebutkan bahwa pemerintah dan lembaga terkait selama ini terus mengupayakan perwujudan kurikulum kebaharian, dan hal tersebut membutuhkan proses yang tidak singkat hingga terealisasi. Kurikulum Kemaritiman Nasional sendiri saat ini sedang disusun oleh Pusat Kurikulum Kementerian Pendidikan dan Kebudayaan (Kemdikbud). Dalam rencana tersebut kurikulum difokuskan pada sekolah-sekolah pesisir maupun yang berdekatan dengan laut. Dengan demikian, Kabupaten Bintan dengan segala potensi dan letak yang strategis akan menjadi salah satu target dari pelaksanaan kurikulum tersebut.

Setiap guru khususnya guru biologi di sekolah menengah pertama di Kabupaten Bintan harus memiliki wawasan luas yang nantinya akan sangat mendukung peran seorang pendidik dalam menjalankan tugasnya menyalurkan pengetahuan yang dimiliki, sehingga dapat menghasilkan generasi muda berwawasan kemaritiman seperti yang diharapkan untuk mewujudkan cita-cita bangsa indonesia sebagai negara poros maritim dunia.

Berdasarkan hasil wawancara dari beberapa siswa sekolah menengah pertama (SMP) Negeri di Kabupaten Bintan, diantaranya siswa SMP
Negeri 5 bintan, siswa SMP Negeri 6 Bintan dan siswa SMP Negeri 17 Bintan menyatakan bahwa kegiatan pembelajaran yang disampaikan oleh Guru biologi belum mengembangkan pemahaman mengenai kemaritiman, sehingga belum mencapai tahap literasi kemaritiman. Beberapa siswa masih ada pula yang belum memahami secara mendalam mengenai kemaritiman. Para siswa hanya mengetahui kemaritiman dalam artian yang sempit seperti hanya pada kelautan dan sumberdaya laut seperti ikan dan terumbu karang. Bahkan, ketika proses wawancara tersebut berlangsung seorang siswa menyatakan bahwa guru disekolahnya tidak pernah menyinggung mengenai kemaritiman.

\section{METODE PENELITIAN}

\section{Waktu dan Tempat Penelitian}

Penelitian ini akan dilaksanakan pada bulan Mei 2017 di sekolah SMP Negeri di Kabupaten bintan diantaranya SMP Negeri 5 Bintan, SMP Negeri 6 Bintan dan SMP Negeri 17 Bintan Tahun ajaran 2017/2018.

\section{Prosedur Penelitian}

Penelitian dilakukan dengan memberikan angket kepada guru sesuai jadwal yang telah disepakati bersama untuk diisi sesuai petunjuk. Melakukan wawancara kepada guru biologi mengenai wawasan kemaritiaman guru danintegrasinya terhadap pembelajarn biologi di sekolah tersebut. Subjek penelitian ini adalah guru biologi SMP Negeri di Kabupaten Bintan, yang terdiri dari guru Biologi SMP Negeri 5 Bintan, SMP Negeri 6 Bintan, dan SMP Negeri 17 Bintan.

Analisis terhadap hasil penelitian dilakukan dengan menggunakan skala likert untuk variabel literasi kemaritiman. Dalam pemilihan respon jawaban terdapat 4 kategori pilihan yaitu SS (sangat sering), S (sering), TS (tidak sering), dan STS (sangat tidak sering). Penskoran terhadap alternatif respon bergerak dari angka 1 sampai dnegan 4. Berikut perinciannya :

Tabel 1. Penskoran Item

\begin{tabular}{|c|c|c|}
\hline Kategori Respon & $\begin{array}{c}\text { Skor Item F } \\
\text { (Favorable) }\end{array}$ & $\begin{array}{c}\text { Skor } \\
\text { Item UF } \\
\text { (Unfavor } \\
\text { able })\end{array}$ \\
\hline SS & 4 & 1 \\
\hline
\end{tabular}




\begin{tabular}{|c|c|c|}
\hline S & 3 & 2 \\
\hline TS & 2 & 3 \\
\hline STS & 1 & 4 \\
\hline
\end{tabular}

Penelitian dilakukan di SMP Negeri 5 Bintan, SMP Negeri 6 Bintan dan SMP Negeri 17 Bintan. teknik sampling dalam penelitian ini menggunakan teknik Porposive sampling. Proposive sampling adalah teknik memilih sampel dengan dasar tujuan tertentu ( Sukardi, 2012 : 64 ). Teknik ini dianggap paling tepat karena pemilihan sampel dalam penelitian ini hanya untuk mengetahui Literasi Kemaritian Guru Biologi di sekolah-sekolah tersebut.

\section{Deskripsi Hasil Penelitian}

Berdasarkan data mentah yang terkumpul dari penyebaran angket pada 3 orang responden, dengan jumlah pertanyaan 20 butir instrumen dengan pilihan jawaban 4 maka dapat di ketahui persentasi skor dari masing-masing indikator sebagai berikut :

Tabel 2. Presentasi Skor Per Indikator

\begin{tabular}{|c|c|c|c|}
\hline No & Indikator & $\sum$ Skor & \% Skor \\
\hline 1. & $\begin{array}{l}\text { Merencanakan } \\
\text { pembelajaran } \\
\text { berbasis } \\
\text { kemaritiman }\end{array}$ & 17 & $35,0 \%$ \\
\hline 2. & $\begin{array}{l}\text { Mengembangkan } \\
\text { soal evaluasi } \\
\text { berbasis } \\
\text { kemaritiman }\end{array}$ & 27 & $56,25 \%$ \\
\hline 3. & $\begin{array}{l}\text { Mengembangkan } \\
\text { media pembelajaran } \\
\text { berbasis } \\
\text { kemaritiman }\end{array}$ & 22 & $36,6 \%$ \\
\hline 4. & $\begin{array}{l}\text { Mengembangkan } \\
\text { sikap ilmiah siswa } \\
\text { dengan yang } \\
\text { mencerminkan } \\
\text { budaya maritim. }\end{array}$ & 25 & $69,4 \%$ \\
\hline 5. & $\begin{array}{l}\text { peka terhadap isu } \\
\text { kemaritiman }\end{array}$ & 21 & $43,75 \%$ \\
\hline & Jumlah & 112 & $46,6 \%$ \\
\hline
\end{tabular}

Dari hasil pengumpulan data tersebut diketahui bahwa rata-rata perolehan skor pada hasil sebaran angket ialah 46,6 \% dimana perolehan skor tertinggi $(69,4 \%)$ terdapat pada indikator " mengembangkan sikap ilmiah yang mencerminkan budaya maritim". Berdasarkan data bahwa literasi kemaritiman guru biologi SMP Negeri di Kabupaten Bintan tergolong rendah. Mengenai skala penilaian prosentase skor dapat di lihat pada tabel 3. 
Tabel.3 Kategori Interval

\begin{tabular}{|c|c|}
\hline Interval & Kategori \\
\hline $81 \%-100 \%$ & Sangat baik \\
\hline $61 \%-80 \%$ & baik \\
\hline $41 \%-60 \%$ & cukup \\
\hline $21 \%-40 \%$ & rendah \\
\hline $0 \%-20 \%$ & Sangat rendah \\
\hline
\end{tabular}

\section{Pembahasan}

Hasil pengujian analisis deskriptif menyatakan bahwa literasi kemaritiman guru biologi SMP Negeri di Kabupaten Bintan dalam pembelajaran IPA khususnya Biologi masih tergolong rendah dengan persentase skor 46,6 $\%$. Artinya guru sekedar memahami mengenai kemaritiman namun belum sampai kepada tahap literasinya, hal ini salah satunya di sebabkan karena kurang memahami secara menyeluruh mengenai kemaritiman dan integrasi wawasan kemaritiman belum sepenuhnya tertuang kedalam materi pembelajaran IPA khususnya biologi. Dalam indikator angket perolehan presentase tertinggi terletak pada "mengembangkan sikap ilmiah yang mencerminkan budaya maritim", hal ini berarti baru aspek sikap yang hampir mencapai kategori baik yaitu dengan jumlah presentase skor 69,4 \% sedangkan untuk indikator lainnya masih tergolong rendah.

Menurut OECD dalam PISA (dalam Aryani, dkk., 2016 : 847) dan Rais (2015 : 11) yang mengadopsi empat domain yang terdapat dalam science literacy, untuk mencapai tahap literasi kemaritiman ada empat dimensi besar (aspek) yang harus di capai, yaitu aspek pemahaman, aplikasi, refleksi dan sikap. Namun berdasarkan data yang di peroleh bahwa Guru Biologi SMP Negeri di Kabupaten Bintan dalam pembelajara IPA khususnya Biologi secara umum baru mencapai aspek pemahaman dan sikap, sedangkan aspek aplikasi dan resfleksi belum tercapai.

Secara umum literasi kemaritiman diartikan sebagai pemahaman mengenai kemaritiman secara menyeluruh, dalam artian tidak hanya paham apa arti dari kemaritiman tetapi mampu mengaplikasikan dan mampu melakukan refleksi diri terhadap lingkungan di sekitarnya, untuk dapat mengetahui kelemahan dan kekuatan serta kontribusi dirinya terhadap kemaritiman di lingkungan sekitarnya (Diana,
2015 : 285 ). Oleh sebab itu dapat dikatakan bahwa profil literasi kemaritiman guru biologi SMP Negeri di Kabupaten Bintan masih rendah. Guru hanya paham mengenai kemaritiman tetapi tidak merefleksikannya dan mengaplikasikannya kedalam kehidupan sehari-hari. Bahkan integrasinya kedalam materi pembelajaran biologi masih sangat kurang.

Persentase rencana pembelajaran berbasis kemaritiman hanya mencapai 35,0 \% yang artinya masih rendah. Secara umum guru belum merencanakan pembelajaran yang mengaitkan kepada kemaritiman. Untuk persentase pengembangan soal evaluasi berbasis kemaritiman mencapai 56,25\% yang artinya cukup. Guru sudah mulai mengembangkan soalsoal evaluasi dengan mulai mengaitkan kepada kemaritiman namun tidak secara menyeluruh. Persentase media pembelajaran berbasis kemaritiman tergolong kedalam persentase yang cukup rendah yaitu $36,6 \%$, artinya guru belum memanfaatkan media alam nyata berbasis kemaritiman seperti pantai sebagai media belajar bagi siswa. Peka terhadap isu lingkungan kemaritiman yang tercantum didalam pembelajaran menunjukkan presentase $43,75 \%$ yang artinya cukup. Sedangkan untuk presentase tertinggi adalah penanaman aspek sikap ilmiah siswa dengan mencerminkan budaya maritim yang mencapai $69,4 \%$ yang dikategorikan baik.

Menurut Undang-undang Republik Indonesia No.14 Tahun 2005 tentang Guru dan Dosen menjelaskan bahwa Guru adalah pendidik profesional dengan tugas utama mendidik, mengajar, membimbing, mengarahkan, melatih, menilai, dan mengevaluasi peserta didik pada pendidikan anak usia dini jalur pendidikan formal, pendidikan dasar, dan pendidikan menengah. Sebagai pengajar atau pendidik, guru merupakan salah satu faktor penentu keberhasilan setiap upaya pendidikan.

Dengan demikian, artinya untuk dapat membangun kembali pengetahuan mengenai kemaritiman kepada generasi muda demi ikut andil mewujudkan cita-cita bangsa sebagai poros maritim, guru memiliki peran yang besar. Guru sebagai tenaga pendidik yang memiliki kompetensi profesional selalu dituntut untuk memiliki wawasan yang luas bukan hanya wawasan bidang yang di ampunya tetapi dalam bidang-bidang lain seperti wawasan mengenai 
kemaritiman serta menguasai keterampilanketerampilan lainnya dalam aplikasinya dalam kehidupan sehari-hari, sehingga nantinya wawasan tersebut dapat disalurkan kepada peserta didik. Sebelum memberikan pengetahuan mengenai kemaritiman, seorang guru harus memahami dahulu mengenai makna kemaritiman secara menyeluruh. Berdasarkan hasil wawancara yang dilakukan kepada Guru biologi SMP Negeri di Kabupaten Bintan, secara umum guru biologi sudah memahami mengenai arti kemaritiman dan menyatakan bahwa setuju jika wawasan kemartiman diintegrasikan kedalam mata pelajaran IPA khususnya biologi. Wawasan kemaritiman dianggap perlu ditumbuhkan kembali mengingat pengetahuan mengenai kemaritiman bersifat kontekstual serta mengingat kepada keadaan Kabupaten Bintan yang di dominasi oleh daerah pesisir pantai. Namun, sampai saat ini, wawasan kemartiman siswa maupun guru masih sangat rendah. Salah satu penyebabnya adalah mulai menghilangnya budaya maritim dalam kehidupan sehari-hari. Selain itu, sulitnya mengintegrasikan pengetahuan kemartiman pada pembelajaran biologi secara menyeluruh, waktu yang terbatas serta kurangnya pemahaman mendalam mengenai makna kemartiman menjadi alasan paling besar untuk menciptakan pembelajaran yang berbasis kemartiman.

Berdasarkan hasil wawancara penelitian terhadap guru biologi SMP Negeri 5 Bintan, SMP Negeri 6 Bintan, dan SMP Negeri 17 Bintan, integrasi mengenai kemaritiman belum seluruhnya diaplikasikan ke dalam semua materi pembelajaran biologi. Pada umumnya sekolahsekolah tersebut belum secara khusus menyusun Rencana Pembelajaran yang berbasis kemaritaman. Berdasarkan hasil wawancara, secara umum terdapat beberapa kendala yang di alami guru dalam mengintegrasikan literasi kemaritiman dalam pembelajaran IPA khususnya Biologi diantaranya :

1. Kedalaman materi.

Berdasarkan yang telah disampaikan narasumber, bahwa secara umum kendala mengintegrasi literasi kemaritiman kedalam pembelajaran IPA khususnya biologi adalah karena faktor kedalaman materi. Pembelajaran biologi di SMP dianggap masih pada tahap umum, sehingga siswa belum di tuntut untuk terlalu detail dalam melakukan pengamatan langsung ke daerah pantai untuk menemukan sendiri maupun memecahkan masalah secara mandiri mengenai pembelajaran yang dikaitkan dengan wawasan kemaritiman. Sehingga dalam rencana pembelajaran belum di khususkan penyusunan yang berbasis kemaritiman. Namun narasumber tetap berpendapat bahwa pemahaman kemaritiman kepada siswa penting dilakukan karena bersifat kontekstual.

\section{Keadaan sekolah}

Keadaan sekolah juga menjadi kendala yang paling signifikan. Jarak sekolah dengan pantai yang membutuhkan waktu cukup jauh menyebabkan guru lebih memilih menggunakan media pembelajaran berupa gambar untuk memperkenalkan wawasan kemaritiman tanpa harus berkunjung langsung ke wilayah pantai. Selain itu, untuk melakukan pengamatan, guru lebih mengarahkan siswa untuk memperhatikan daerah sekitar sekolah dari pada harus berkunjung ke pantai. Selain membutuhkan biaya yang cukup besar, waktu yang dibutuhkan juga cukup banyak dan untuk meminimalisir alokasi waktu pembelajaran, siswa lebih sering mengamati keadaan sekolah yang pada umumnya perkebunan sebagai media pembelajaran langsung yang nyata. Hal tersebut mengakibatkan siswa lebih mengenal ekosistem perkebunan dari pada ekosistem pantai.

3. Kesesuaian materi pembelajaran dengan kemaritiman.

Narasumber menyatakan bahwa tidak semua materi pembelajaran biologi dapat dikaitkan dengan kemaritiman. Sehingga integrasi literasi kemaritiman pada materi biologi hanya pada beberapa materi saja. Pengembangan soal evaluasi berbasis kemaritiman juga tergolong rendah, hal ini disebabkan karena kecendrungan siswa lebih sering mengamati daerah daratan dari pada pantai, sehingga guru kurang mengembangkan soal-soal evaluasi berbasis kemaritiman kecuali pada materi tertentu. Narasumber juga berpendapat bahwa 
merasa kesulitan dalam mengembangkan soal-soal evaluasi yang berbasis kemaritiman, karena guru tersebut juga tidak terlalu paham mengenai konsep kemaritiman secara menyeluruh.

\section{DAFTAR PUSTAKA}

Arikunto, Suharmi. 2013 . Prosedur Penelitian: Suatu Pendekatan Praktik. Jakarta : Rineka Cipta.

Bappenas, 2015. Laporan pencapaian tujuan pembangunan milenium di Indonesia. 2014. Jakarta.

Bappeda Kab. Bintan. 2012. Rencana Tata Ruang Wilayah Kabupaten Bintan. Pemerintah Kabupaten Bintan.

Diana, Sariwulan, dkk.2015.'Profil Kemampuan Literasi Sains Siswa Berdasarkan Instrumen SLA (Scientific Literacy Assesment)". Seminar Nasional XII Pendidikan Biologi FKIP UNS, 2015. Hal. 285291.

Lasabuda, Ridwan. 2013. Pembangunan Wilayah Pesisir dan Lautan Dalam Perspektif Negara Kepulauan Republik Indonesia. UNSRAT : Jurnal Ilmiah Platax. Vol.1 No. 2. 93-101.

OECD.2016. PISA 2009 Results: What Students Know and Can Do -Student Performance in Reading, Mathematics and Science (Vol. 1). http://dx.doi.org. 15 Mei 2017.

Rais, Misi. 2015. Inovasi Pembelajaran yang berorientasi soft skills. Surabaya : Adiperkasa.

Sugiono. 2013. Metode Penelitian Pendidikan(Pendekatan Kuantitatif, Kualitatif, dan $R \& D$ ). Bandung : Alfabeta.

Sugiono. 2014. Metode Penelitian Kuantitatif, Kualitatif, dan $R \& D$. Bandung : Alfabeta.

Suhartono, Agus. 2014. Analisis Peluang Dan Ancaman Keamanan Maritim Indonesia. Universitas Gajah Mada. Jurnal.Vol 4. No.1.

Tenda. 2014. Hakekat Peran Guru. skripsi. Gorontalo : Univrsitas Negeri Gorontalo.
UNESCO Education Sector. The Plurality of Literacy and Its Application for Policies and Program. http://unesdoc.unesco.org. 17 Mei 2017. 